\title{
Claude Prudhomme, Missions chrétiennes et colonisation xvie-xviiie siècles
}

Paris, Le Cerf, coll. " Histoire du Christianisme », 2004, $172 \mathrm{p}$.

René Luneau

\section{CpenEdition}

Journals

Édition électronique

URL : http://journals.openedition.org/assr/3600

DOI : 10.4000/assr.3600

ISSN : $1777-5825$

Éditeur

Éditions de l'EHESS

Édition imprimée

Date de publication : 1 mai 2006

Pagination : 147-299

ISBN : 2-7132-2092-0

ISSN : 0335-5985

Référence électronique

René Luneau, "Claude Prudhomme, Missions chrétiennes et colonisation xvie-xviiie siècles », Archives de sciences sociales des religions [En ligne], 134 | avril - juin 2006, document 134-68, mis en ligne le 11 septembre 2006, consulté le 21 septembre 2020. URL : http://journals.openedition.org/assr/3600 ; DOl : https://doi.org/10.4000/assr.3600

Ce document a été généré automatiquement le 21 septembre 2020

(c) Archives de sciences sociales des religions 


\title{
Claude Prudhomme, Missions
} chrétiennes et colonisation xvie-xviiie siècles

\author{
Paris, Le Cerf, coll. « Histoire du Christianisme », \\ 2004, $172 \mathrm{p}$.
}

René Luneau

1 Reconnu de nos jours, et à juste titre, comme l'un des meilleurs spécialistes de l'histoire des missions chrétiennes, C. Prudhomme, professeur d'histoire contemporaine à l'Université de Lyon II, nous offre dans ce petit livre une synthèse, à tous égards remarquable, de cinq siècles d'une histoire particulièrement mouvementée. Dans l'impossibilité, dans le cadre de ce compte rendu, d'en évoquer toute la richesse et la complexité, rappelons qu'en plein $\mathrm{xVI}^{\mathrm{e}}$ siècle et face aux excès de la colonisation espagnole des Amériques, des théologiens comme Las Casas ou Vitoria posèrent des questions essentielles sur le «droit à la colonisation ». Un siècle plus tard (1622), et avec des fortunes diverses, Rome, en instituant une Congrégation dite de la «Propagation de la foi », s'efforça de contrôler les visées politiques d'un régime de « patronat » qu'il avait pourtant accordé au Portugal et à l'Espagne, et de lutter contre un gallicanisme soucieux de ses droits.

2 C'est au XIX ${ }^{e}$ siècle, bien sûr, que les rapports entre missions et colonisation furent les plus étroits, non, parfois, sans conflits ouverts entre Églises et États, la visée de l'évangélisation mise en œuvre par les premières, qu'elles soient catholiques ou protestantes, divergeant notablement des ambitions coloniales. Même s'ils se concertèrent souvent et se rendirent maints services, missionnaires, marchands et militaires ne marchèrent pas toujours la main dans la main. Et quand vint le temps de la "décolonisation", les Églises devancèrent souvent les instances politiques et, dit l'auteur, « d'une manière générale, les Églises ont accompagné la décolonisation avec le souci d'assurer des transitions en douceur", les communautés protestantes, non soumises à un pouvoir central, étant en général les plus ouvertes aux processus en 
cours, à l'exception notable de quelques Églises d'Afrique du Sud qui soutiendront l'apartheid.

3 Trop brève évocation de la richesse d'un petit livre couvrant cinq siècles d'histoire et appelé à rester, pendant très longtemps, une référence fort utile pour ceux et celles qui s'intéressent non seulement aux missions, qu'elles soient catholiques ou protestantes, mais plus encore aux continents qu'elles ont durablement marqués. 